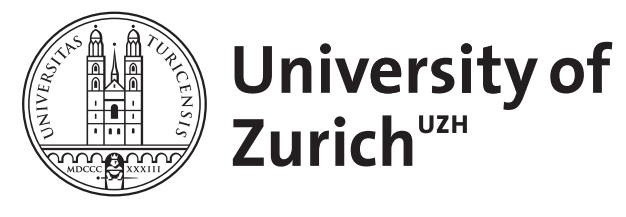

Zurich Open Repository and Archive

University of Zurich

University Library

Strickhofstrasse 39

CH-8057 Zurich

www.zora.uzh.ch

Year: 2012

\title{
Phonological inventories
}

Schreier, Daniel

Posted at the Zurich Open Repository and Archive, University of Zurich

ZORA URL: https://doi.org/10.5167/uzh-71070

Book Section

Published Version

Originally published at:

Schreier, Daniel (2012). Phonological inventories. In: Hickey, Raymond. Areal Features of the Anglophone World. Berlin and New York: Walter de Gruyter, 277-297. 


\title{
Phonological inventories
}

\author{
Daniel Schreier
}

\section{Introduction}

No generally accepted definition of the term 'linguistic area' has been offered to the present day; the concept is "notoriously fuzzy" (Heine and Kuteva 2001: 396) and "what we understand about linguistic areas is depressingly meager" (Thomason 2001: 99). Any definition necessarily makes reference to well-researched change phenomena such as language contact and borrowing and must account for why certain structural features are shared in a given geographical area - typically borrowed words, less often (but more diagnostic) phonological and morphosyntactic structures (Thomason and Kaufman 1988). The best-known linguistic area is the socalled Sprachbund, alternatively known as diffusion or convergence area (van der Auwera 1998); it has been debated intensely whether the features in question are shared due to direct transmission in face-to-face contact (the prerequisite of borrowing), and thus diffused, or whether they are inherited from a common parent language (e.g. Latin in the case of French and Italian, Proto-Germanic in the case of Dutch and Norwegian, etc.; cf. Campbell 1998), a dispute that arguably contributes to the general 'fuzziness' attributed to the term (see below).

What is clear, however, is that phonological features have played a prominent role in linguistic analysis and some progress has been made as to why features are shared within and across dialect areas. In traditional dialect geography, most importantly (e.g. the Survey of English Dialects; Orton 1962-1971), dialect areas were singled out, defined and mapped along criteria such as whether or not they shared a pre-specified set of features. Dialectologists and historical linguists alike have scrutinised why and where features make an appearance in dialects that coexist in a particular region and offered two main explanations for the sharing of features. These, too, fall into the two categories of inherited vs. diffused, which suggests that there are close links between dialect geography and areal linguistics. For one, it has been suggested that features are shared because of ancestral links to an earlier ('mother') dialect (spoken in the very same area; the link to historical linguistics is obvious), or else that this 
would be the result of area-internal diffusion from one variety to another (as in wave or cascade models; see Chambers and Trudgill 1998, Chambers, this volume).

Consequently, the analysis of areal features draws on a range of fields, dialectology, sociolinguistics and historical linguistics, to name but three of the major ones; the particular appeal of English areal features is that the 'export' around the globe has triggered a plethora of diffusion phenomena that operated in contact settings with distinct sociodemographic and sociolinguistic characteristics. The extension of phonological areas began with the transplantation of English to areas other than Great Britain, starting with the Caribbean and North America in the late sixteenth and seventeenth centuries and later into India, Africa, the Southern Hemisphere and the Far East. As has been discussed in detail elsewhere (e.g. Hickey 2004), the great number of offspring varieties of English as a world language had large-scale phonological consequences. New varieties sprang up in their own distinctive contact settings, drawing on feature pools (Mufwene 2001) that involved English as a main input (at times the lexifier) as well as other superstrates (colonial ones, such as French, German, Spanish or Dutch) and local indigenous substrates. The endproducts of these processes, new varieties of English in the form of koinés, pidgins or creoles (discussion in Schreier 2008; cf. Trudgill 2004) have both a linguistic and a social grounding.

Mufwene (2001) argues that the social relationships between individual ethnic groups have consequences for the directionality and future development of contact-derived varieties. Departing from a creolist viewpoint, he claims that the predominance of lexical input from the superstrate variety is a linguistic reflection of the unequal balance between different ethnic groups present, which attests to the influence and high prestige of the socially powerful group. This view is also adopted by Hickey (2003) and Thomason and Kaufman (1988), who emphasize the importance of extralinguistic factors when saying that "[i]t is the sociolinguistic history of the speakers, and not the structure of their language, that is the primary determinant of the linguistic outcome of language contact. Purely linguistic considerations are relevant but strictly secondary overall." (Thomason and Kaufman 1988: 35). Others, in contrast, claim that the linguistic properties are of more importance, going as far as to argue that they can be predicted solely on condition that sufficient demographic information is available on the overall proportions of transplanted donor varieties (Trudgill 2001: 44).

When looking at phonological inventories of English in general and shared phonological features in particular, we must first address the question whether they diffused from one variety to the other (via borrow- 
ing) or whether they were inherited and have thus been preserved in the varieties coexisting in a particular region. One of the best-known examples of diffusion in (British) English dialectology manifests itself by the distribution of the two systems of five vs. six short vowels, which is certainly one of the most prominent and diagnostic characteristics of dialect variation in the UK. This distribution can be explained historically, simply by whether or not regional dialects have participated in the FOOT-STRUT split, which started when Middle English short /u/ split into two distinct phonemes FOOT and STRUT (Wells 1982). This change started in the South of England in the mid-seventeenth century (Wells 1982: 197) and diffused well throughout the South but was not adopted in the English midlands and the North of England varieties (see Britain, this volume).

In what follows, I focus on two variables, one phonotactic (the reduction of word- and/or syllable-final consonant clusters to simple consonants) and one phonological (rhoticity, i.e. global variation with regard to presence or absence of post-vocalic $/ \mathrm{r} /$ after vowels and before pauses). These two features are discussed with reference to historical phonology (particularly of British English), variation and change models and also in terms of their relevance for contact-induced language change and the persistence of universal features (Chambers 2003, 2009), showing that the dividing line between shared, diffused and universal features is necessarily blurred (which may be instrumental in explaining why the concept is so "notoriously fuzzy") and to some extent the product of external criteria such as settlement history.

\section{Phonological inventories I: Universals and contact-sensitivity}

The first variable discussed here are clusters of consonants in English and their ubiquitous avoidance strategies. This by and large falls into the domain of phonotactics: "the sequential arrangements (or 'tactic behaviour') of phonological units ... In English, for example, consonant sequences such as /fs/ or /spm/ do not occur initially in a word, and there are many restrictions on the possible consonant + vowel combinations which may occur ... These sequential constraints can be stated in terms of "phonotactic rules"" (Crystal 1991: 263). Important factors are that consonant clusters are linguistically marked (they occur late in language acquisition, they make a manifestation in a minority of the world's languages only, etc.) and that other syllable types (Consonant-Vowel CV, or Consonant-Vowel-Consonant $\mathrm{CVC}$ ) are much more common in contrast. English is thus one of the 
comparatively few languages that admit groups of consonants in syllables, both in onset and coda (Figure 1).

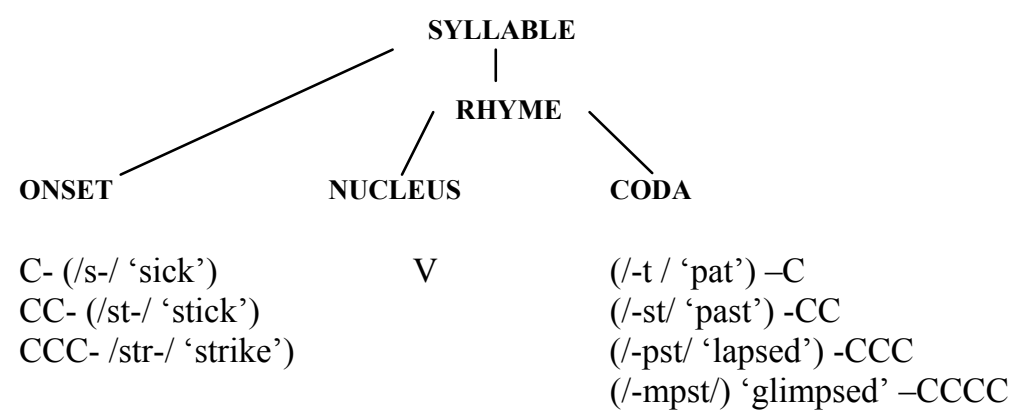

Figure 1. Consonant clusters and English syllable structure

By the same token, all varieties have a tendency to reduce these clusters. The process called Consonant Cluster Reduction (CCR) is so common that Chambers (1995: 242) has identified it as one of the "vernacular roots" of English, a concept that has given rise to considerable discussion over the last decade (Filppula, Klemola and Paulasto 2009). This process is of particular interest to variationists since it is subject to two common constraints:

\section{1) Status of segment clusters}

(monomorphemic clusters (past, desk or find) are more prone to undergo reduction than bimorphemic clusters (passed, stopped or knocked). CCs are more robust when some of their segments carry morphological meaning, i.e., when they include more than one morpheme: CC monomorph. (/st/ in past) $>\mathrm{CC}$ bimorph. (/st/ in passed).

2) Phonetic environment

(the influence of the CC's immediately following phonetic segment. $\mathrm{CCs}$ followed by another consonant are more frequently reduced than CCs followed by a pause or a vowel: $\mathrm{C}>\mathrm{P}>\mathrm{V}$ ).

CCR is at least in part a phonetically conditioned process which, among others, has been attributed to syllable structure and potential for resyllabification (so that it can resyllabify onto the onset of the following syllable and result in an acceptable and phonotactically well-formed syllable across a morpheme boundary, Guy 1991, 1994, Labov 1997). Four decades of research on this variable in English varieties around the world have shown 
that the two constraints of (following) phonetic environment and morphemic status are extremely common; in fact, they are so regular and pervasive that it has been labelled the "showcase variable for variationist sociolinguistics" (Patrick 1991: 171).

This variable can make an important contribution to the study of English areal linguistics. If this is a universal feature indeed (cf. Schreier 2005), then we can investigate regional CCR manifestations with the aim of identifying how often this process occurs and whether there are local preferences for the constraints (is one of them more prominent in a certain region?). Given its global status, one can ask how consonants change their "phonotactic behaviour" in clusters as English diversifies around the globe, what processes of phonotactic divergence there are, and what areal tendencies we can trace. As argued elsewhere (Schreier 2005), there exist at least four possible trajectories of phonotactic variation and change in English, particularly in what regards the frequency with which clusters are reduced, the total number of clusters that can undergo this process, and differential effects related to segment status or alternative epenthesis techniques. These regional or variety-specific preferences are indicative of language contact und substratal influence (particularly in ESL/EFL varieties, creolisation, bilingualism, etc.).

Starting with the most widely attested CCR pattern, we find that varieties such as White American English (North Carolina; Wolfram and Thomas 2002) are subject to strong effects conditioned by the nature of the cluster segment (mono- or bimorphemic) and the nature of the phonetic environment (consonant, pause or vowel). Table 1 shows the constraint hierarchy. The overall frequency of the process varies drastically from $58.6 \%$ (in monomorphemic clusters with a following consonant) to $4.1 \%$ (in bimorphemic clusters followed by a vowel, see above). This pattern is extraordinarily consistent since it is also attested in early twentieth century New Zealand English, which suggests that this variable is stable in contact processes accompanying new-dialect formation. 
Table 1. CCR rates in Hyde County NC English (from Wolfram and Thomas 2002: 142)

\begin{tabular}{lllllll}
\hline & Pre-C & \multicolumn{3}{c}{ Pre-P } & \multicolumn{3}{c}{ Pre-V } \\
& mono & $b i$ & mono & $b i$ & mono & $b i$ \\
\cline { 2 - 7 } & & & & & & \\
reduced & 123 & 48 & 23 & 3 & 14 & 7 \\
realised & 87 & 69 & 47 & 45 & 129 & 162 \\
\% CCR & $\mathbf{5 8 . 6}$ & $\mathbf{4 1 . 0}$ & $\mathbf{3 2 . 9}$ & $\mathbf{6 . 3}$ & $\mathbf{9 . 8}$ & $\mathbf{4 . 1}$ \\
\hline
\end{tabular}

However, the diversity of contact scenarios of varieties of English around the world often involves interaction and exposure to typologically unrelated varieties (e.g. African substrates in the formation of African Englishes), so the next question is how English syllable structures, particularly $\mathrm{CCs}$, are modified during language contact. How does the process of CCR manifest itself when there is input of other systems spoken by other speech communities? The question is actually two-fold. First, from a purely quantitative point of view, it is paramount to ask how often clusters are reduced; from a qualitative one, the question is whether the established British and American pattern holds across the board, so that it is just as universal as Chambers' vernacular roots, or whether CCR affects other clusters as well, which, given its diagnosticity, would give rise to some speculation.

In terms of quantity, a look at the literature indicates that varieties differ very much in as to how often this process applies. This is exemplified by a comparison of global reduction values in English(es) around the world:

York (UK) English

New Zealand English

White American English

(Hyde County NC)

Philadelphia English

African American English

Hispanic varieties

Caribbean creoles
24\% (Tagliamonte and Temple 2005: 12)

$28 \%$ (Schreier 2005)

28.8\% (Wolfram and Thomas 2002: 136)

33\% (Guy 1991)

13-44\% (Poplack and Tagliamonte 2001, Table 6.1)

50\% (Bayley 1994, Santa Ana 1996)

50-97\% (Poplack and Tagliamonte 2001, Table 6.1) 
Mesolectal Jamaican English 75\% (Patrick 1999: 152)

St Helenian English

$87 \%$ (Schreier 2005)

High CCR is reported in English-derived creoles (St Helenian English, Caribbean varieties) and in varieties that have had extensive histories of language contact and potential of substratum interference (Hispanic English, African American English). Varieties that derive from British English, on the other hand, White American, British, or New Zealand English, typically have low CCR values (unless they were subject to extensive (language) contact), ranging between 24 and 33\%. As a result, CCR increases quantitatively in language contact scenarios (bilingualism, pidginisation, creolisation, ESL/EFL development) and global statements concerning the manifestation of CCR (e.g. in Kortmann et al. 2004) would benefit from a more informed quantitative perspective.

This is even more important since internal constraints may undergo change as well: while mesolectal Jamaican Creole English (Patrick 1991, 1999) and St Helenian English have following segment constraints, bimorphemic clusters have in fact higher reduction rates than monomorphemic clusters (Table 2 and Figure 2), which means that the constraint hierarchy is reversed. Following Patrick (1999), this is most plausibly explained by the lack of morphological tense marking and its compensation with an analytical system or pre-verbal items, i.e. the reliance on tense markers such as done, did, been, yuustu, etc. This indicates that, against common belief (see Chambers 2009), there is variation in the constraint hierarchy of CCR. The bi>mono constraint is thus extremely diagnostic and indicative of contact-induced change phenomena. In fact, it is remarkable that there are no connections between mesolectal Jamaican Creole English and St Helenian English. Diffusion cannot serve as an explanation here and it is extremely unlikely that there was inheritance since this pattern is not attested in British inputs. Consequently, we are most likely looking at a case of independent development in two unrelated varieties. It is worth developing this issue further and check whether this is a more wide-spread creole feature but, awaiting more empirical and quantitative research, the question cannot be answered for the time being. What we know is that other creoles, such as Bahamian English, are in agreement with the common mono>bi pattern (Childs, Reaser and Wolfram 2003). 
Table 2. CCR in St Helenian English (Schreier 2008)

\begin{tabular}{|c|c|c|c|c|c|c|}
\hline & Pre-C & & Pre-P & & Pre-V & \\
\hline & mono & $b i$ & mono & $b i$ & mono & $b i$ \\
\hline reduced & 521 & 123 & 146 & 29 & 275 & 115 \\
\hline realised & 38 & 123 & 27 & 2 & 111 & 13 \\
\hline$\% \mathrm{CCR}$ & 93.2 & 100 & 84.4 & 93.5 & 73.8 & 89.8 \\
\hline
\end{tabular}

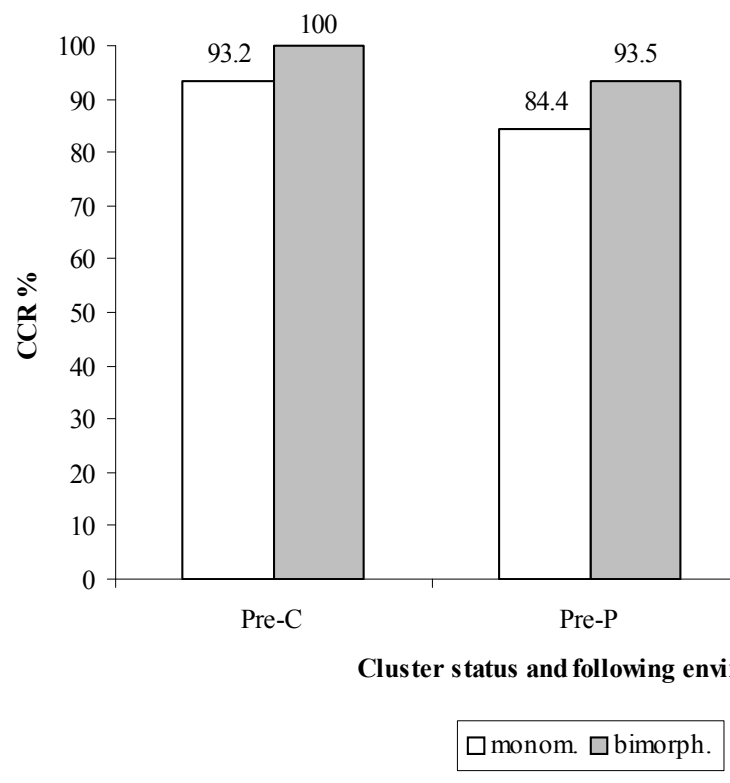

Figure 2. CCR in St Helenian English (Schreier 2008)

Moreover, in British and American English, CCR can only operate when both cluster segments are voiced or unvoiced. The so-called voicing constraint (Fasold 1972) manifests itself in that only clusters with homovoiced segments can be reduced (i.e., both consonants are either +VOICE or -VOICE): $-s t,-b d$, -ld, etc., but not $-l k,-m p$, etc. Again there is evidence that this constraint is weakened in other varieties of English around the world. In Indian English, Khan (1991) noted that coda-final plosives in 
hetero-voiced clusters are as frequently reduced as homo-voiced ones. ESL varieties thus appear to apply this rule more often (and to more clusters). This is indicative of rule generalisation; a constraint present in the target (superstrate) variety is adopted yet generalised and applied to a larger number of potential candidates. As a result, the voicing constraint is not operative, or at least less rigid, in ESL or EFL varieties and probably in English-derived pidgins and creoles as well.

Finally, it is equally important to focus on alternative strategies. Phonotactic modification (and avoidance of CCs) can also be achieved through the insertion of vowels (epenthesis). McArthur (1992) lists this technique in a variety of Englishes, such as Pakistani English (p. 742), Singapore English (p. 938) or Uganda English (p. 1067). Khan (1991) reports this in IndE as well: "Many Indian languages do not have final clusters, and most Indian speakers seem to find final clusters difficult, often tending to break them either by inserting [I] or [ə] in the middle of the cluster or by deleting the final stop completely" (p. 291). This is also common in Asian EFL varieties (Table 3).

Table 3. Cluster modification strategies in Korean EFL (from Lee 2000)

\begin{tabular}{|c|c|c|c|}
\hline Cluster set-up & Epenthesis & $\begin{array}{l}\text { Final C } \\
\text { insertion }\end{array}$ & Example \\
\hline liquid + nasal & $\checkmark$ & & film $[$ filum $\sim$ filim $]$ \\
\hline liquid + plosive & & $\checkmark$ & $\begin{array}{l}\text { help }\left[\text { help }{ }^{\mathrm{h}} \mathrm{u}\right], \text { milk } \\
{\left[\text { milk }^{\mathrm{h}} \mathbf{u}\right]}\end{array}$ \\
\hline nasal + plosive & & $\checkmark$ & $\begin{array}{l}\text { lamp }\left[1 \varepsilon m p^{h} u\right], \text { rinse } \\
\text { [rinsu }]\end{array}$ \\
\hline plosive + plosive & & $\checkmark$ & $\begin{array}{l}\left.\text { adopt [ədopt }{ }^{\mathrm{h}} \mathbf{u} \sim \operatorname{\partial dapt}^{\mathrm{h}} \mathbf{u}\right], \\
\operatorname{act}\left[\varepsilon \mathrm{kt} \mathrm{t}^{\mathrm{h}} \mathbf{u}\right]\end{array}$ \\
\hline fricative + plosive & $\checkmark$ & $\checkmark$ & $\operatorname{lisp}\left[\operatorname{lisp}^{\mathrm{h}} \mathrm{u}\right]$, left $\left[\right.$ lefut $\left.\mathrm{t}^{\mathrm{h}} \mathrm{u}\right]$ \\
\hline plosive + fricative & & $\checkmark$ & $\begin{array}{l}\text { lapse [lepsu], fox [foksu } \\
\text { faksu] }\end{array}$ \\
\hline $\begin{array}{l}\text { plosive }+ \text { fricative } \\
+ \text { plosive }\end{array}$ & $\checkmark$ & $\checkmark$ & $\begin{array}{l}\text { text }\left[\mathrm{t}^{\mathrm{h}} \text { eksut }{ }^{\mathrm{h}} \mathrm{u}\right], \text { midst } \\
{\left[\text { midust }{ }^{\mathrm{h}} \mathrm{u}\right]}\end{array}$ \\
\hline $\begin{array}{l}\text { nasal }+ \text { plosive } \\
+ \text { plosive }\end{array}$ & $\checkmark$ & $\checkmark$ & 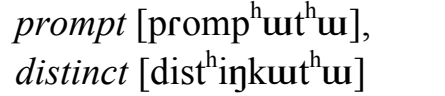 \\
\hline
\end{tabular}


To conclude, CCR is one of the features that considerably challenge a straightforward regional taxonomy of English varieties. While it is a universal (or, according to Mair 2003, an "angloversal"), it is sensitive to contact-induced language change. This is supported when we take a general look at CCR in English around the world. Using the Handbook of Varieties of English (Kortmann et al. 2004) as a research tool, a high percentage of CCR is indicative of large-scale language contact, making an appearance in nearly all English-based creoles. The authors use a taxonomic classification of features classed into three groups: (A) 'Feature(s) pervasive/very frequent'; (B) 'Feature(s) occur sometimes, in some groups/in some environments'; and (C) 'Feature(s) not documented: no positive evidence, does not apply or no information available'. Varieties classed as (C) include White varieties of American, British, South African, Australian and New Zealand English, (B) many varieties of American English (particularly ethnic ones), Cameroon English, Malaysian English, Black SAfrE and Indian English, and (A) Aboriginal English, Australian Creoles, Bahamian English, Belizean Creole, Bislama (Vanuatu), Butler English (India), Cameroon Pidgin English, Earlier AAE, Ghanaian Pidgin, Gullah, Hawaiian Creoles, Jamaican Creole, Liberian Settler English, Solomon Islands Pijin, Tok Pisin, and Trinidadian Creole (Figure 3, adapted from Kortmann et al. 2004).

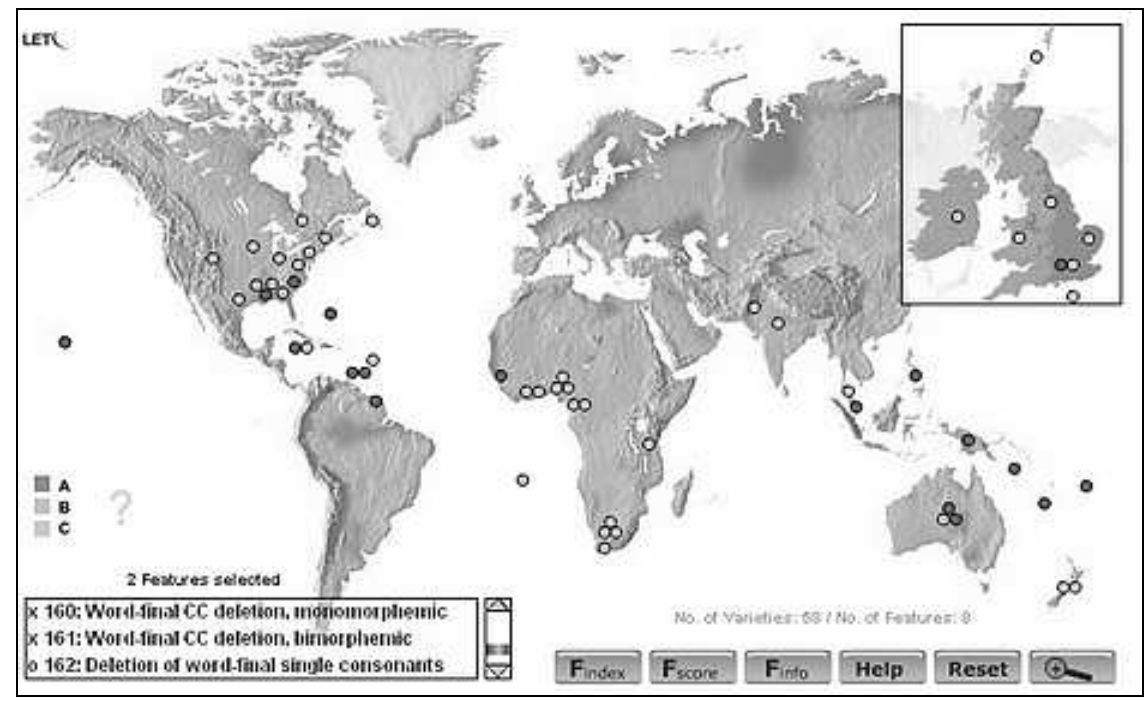

Figure 3. Consonant Cluster Reduction in varieties of English around the world (adopted from Kortmann et al. 2004) 
To sum up, the diagnostic constraint hierarchies (bi>mono), alternative strategies such as epenthesis (e.g. in Asian varieties) and overall frequencies indicate strongly that CCR manifestation in World English is primarily a regionally-specific contact phenomenon, so that this is a prime indicator of areal differentiation indeed. One reason is that, as a result of language contact, linguistically unmarked structures $(\mathrm{CV}, \mathrm{CVC})$ compete with (and have a natural advantage over) syllable types that contain consonant clusters: given the advantage of unmarked items, it is evident that CCR should increase in language contact conditions. This is why it is particularly high in ESL, EFL varieties, bilingual contexts, and found to a great extent in English-based pidgins and creoles. At the same time, we can state: 1) that native-speaker constraints are weakened due to substratal influence and phonotactic transfer of non-English structures; 2) that the reduction rule is applied more often; and 3) that it operates on a larger number of clusters with different structural characteristics (even if they are hetero-voiced, as in Indian English).

By the same token, non-native ESL or EFL varieties deserve a special mention since they display tendencies typically not found in varieties of $\mathrm{BrE}$ or $\mathrm{AmE}$ (as witnessed in many varieties of Asian English, where there is a strong trend towards [i] or [u] epenthesis to break up English clusters). The result is a qualitative phonotactic difference that is a diagnostic tool to distinguish individual varieties of English around the world, and at the present moment it is plausible to suggest that these developments become stronger as English continues to diversify. The further we move away from native-speaker norms, the more influence through language contact we take into account, the more diversity there is with regard to this vernacular root. This may be instrumental for the continuing diversification of English as a global language and will have consequences for the implementation of phonological inventories in English areal linguistics.

\section{Phonological inventories II: Diffusion and legacy}

Much has been written about the spread of English. Over the last four hundred years, it was brought out of the British Isles first to the Caribbean and then North America, later into the Southern Hemisphere and to Asia. The historical export gave rise to diversification as English came to be used alongside other languages in multilingual communities, as it was restructured due to contact between speakers and their typologically different 
varieties, and as it was increasingly often used as a second or foreign language. The complexity of understanding the regional patterning of phonological inventories also derives from the fact that such a spread was not a synchronic process (it occurred over more than three centuries), that it was not sociologically homogeneous (there were different immigration waves and different proportions of founding populations) and also that it involved distinct input varieties, all of which needs to be taken into consideration as well.

The second feature analysed here, rhoticity, goes some way to explain phonological inventories as a socio-historical legacy and highlights areal preferences from a diachronic perspective. Rhoticity is an ideal variable since there has been lots of research from historical linguists, dialectologists and sociolinguists alike. While historical linguists (e.g. J. Milroy 1992, Lass 2006) have looked into the timing of the change from $/ \mathrm{r} /$ $>\varnothing$ in earlier stages of the language, dialectologists are interested in the regional manifestation (where $/ \mathrm{r} /$ is pronounced in words such as yard or car and where not) and sociolinguists (Labov 1972) scrutinise patterns of social stratification, i.e. differences in how often the phoneme is pronounced in different social strata of one and the same speech community, in order to track variation and the dynamic process of language change.

By and large, there is agreement that varieties of English can be distinguished as to whether or not they are rhotic. According to Wells (1982: 75-76), one of the first to discuss rhoticity as a global feature:

In rhotic accents /r/ can occur, with an overt phonetic realization, in a wide variety of phonetic contexts, including pre-consonantal and absolute-final environments, thus farm [farm], far\# [far]. In the non-rhotic accents $/ \mathrm{r} /$ is excluded from pre-consonantal and absolute-final environments, thus farm [fa:m], far\# [fa:].

In rhotic accents, such as Scottish, Irish and North American English, $/ \mathrm{r} /$ is pronounced in all environments, regardless whether it follows a vowel (caress) or precedes consonant (cart) or whether it is in word- or syllablefinal position (car). Speakers with non-rhotic accents, in contrast, pronounce $/ \mathrm{r} /$ in pre-vocalic environments only. Figure 4 (adapted from the research tool developed by Kortmann et al. (2004) indicates that rhoticity is regionally confined and that varieties differ as to whether they have this feature or not. Varieties where rhoticity is classed as (A) include Irish, Scottish and Welsh English, Pakistani English, Philippines English, Trinidadian Creole, and most varieties of American and Canadian English; under (B), we find Jamaican and Bahamian English, African American 
English and New England American English, and Singapore English; and in (C), there are the English South and Southeast, all of Africa, Malaysia, India and Australasia. (Figure 4, adapted from Kortmann et al. 2004).

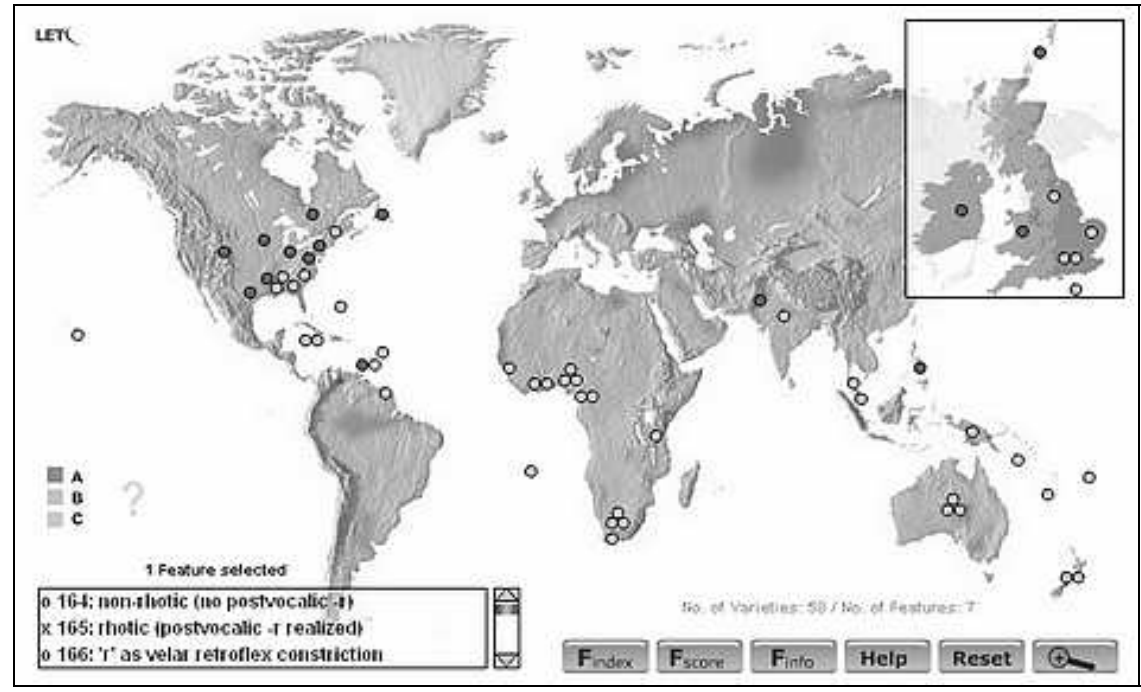

Figure 4. Rhoticity in varieties of English around the world (adopted from Kortmann et al. 2004)

The emerging pattern is at the same time tidy and fuzzy. Whereas African varieties, Australian English and Southern English English varieties are categorically non-rhotic, the Caribbean and North America are highly variable. The only varieties of AmE labelled as non-rhotic or variably rhotic are Gullah, Southern AmE and New England AmE. At the same time, some varieties, e.g. Jamaican English (JamE), fall in-between these two categories in that they are "semi-rhotic" (Wells 1982: 76, 221). Pre-V $/ \mathrm{r} /$ is always present (just as in non-rhotic accents) but variable in pre-C and word-final positions. In other words, rhoticity in present-day JamE thus takes an intermediate position and is characterised by a considerable degree of variability. Stress seems to be an important criterion; whereas $/ \mathrm{r} /$ is dropped from unstressed syllables (water, flower, etc.) it is frequently (though not categorically) present in stressed syllables at the end of a word (car, spare, etc.). Consequently, to follow Lass (2006: 91): "Scotland, Ireland, SW England, a portion of west Lancashire, and most of the US and Canada are rhotic; the rest of England, parts of the US eastern seaboard and Gulf coast, South Africa, Australia and most of New Zealand are non- 
rhotic. So loss of $/ \mathrm{r} /$ is relatively late and geographically restricted. It is also gradual and complex."

The central question for anybody interested in the manifestation of regional phonologies of English around the world is: Why do we find this particular criss-cross pattern and not another one (that could have emerged alternatively)? What, if any, is the motivation for this particular distribution? Stating that this is "a gradual and complex" phenomenon is one thing, explaining it another one. Again, just as in the case of CCR, one might argue that the nature and intensity of contact is an important factor. For instance, it is striking to note that most pidgins and creoles (both in the Atlantic and in the Pacific) are non-rhotic, so transfer of CV syllable structures seems a likely option here as well. When looking at Africa, for instance, we find that all of the West AfrE varieties are non-rhotic and the same goes for Tok Pisin, Bislama and Solomon Islands Pijin. However, there are exceptions where this is not the case.

In the Caribbean, Bahamian and Jamaican English are partially rhotic (especially in their acrolectal forms), which clashes with Gullah and Suriname Creole, all of which are non-rhotic. Basilectal Trinidadian Creole is classified as 'rhotic', on the other hand. So, whereas contact may play a role again, there is an anomaly to account for, namely that varieties shaped under similar social and sociolinguistic conditions behave differently. ${ }^{1}$

How to explain this? At the risk of simplification, the division of the anglophone world is one of a northern hemisphere, settled from approx. 1600 onwards, and a southern hemisphere, settled from approx. 1800 onwards. This means we have to deal with substantially different inputs since 1) BrE provided a most influential donor variety in all the colonies and territorial possessions, and 2) quite a few changes occurred in BrE over these two centuries. As a result, we have to take into consideration that the inputs in the nineteenth century were distinct from those in the seventeenth century and that we have to filter in time depth as well.

Historical linguists and sociolinguists (Bailey 1996, Strang 1970, Lass 1970, J. Milroy 1992) have shown that the loss of rhoticity most probably started in the early fourteenth century. According to Lass (2006: 91), "This is in fact the second episode of $/ \mathrm{r} /$-loss. The first is sporadic, without lengthening, and starts around 1300. Typical relics are ass 'arse' (US, SW England) $<\mathrm{OE}$ ears, bass (fish) $<\mathrm{OE}$ boers. These scattered survivors represent something once more widespread, as attested by occasional

${ }^{1}$ Rhoticity in Caribbean varieties of English, such as Barbadian English, might well be the result of British and Irish settler speech during the Homestead Phase in the early seventeenth century Caribbean (Hickey, p.c., May 2012). 
spellings from the fifteenth to eighteenth centuries, like cadenall 'cardinal', passons 'persons', hash 'harsh'." The change lingers on, is noticed occasionally (documented by J. Milroy 1992), but it is only in the seventeenth and eighteenth centuries that it finally gathers momentum:

i. the shift from consonantal to vocalic $r$, though sporadic earlier, gathered force at the end of the eighteenth century. (Bailey 1996: 100)

ii. in postvocalic position, finally or pre-consonantally, $/ \mathrm{r} /$ was weakened in articulation in the seventeenth century and reduced to a vocalic segment early in the eighteenth century. (Strang 1970: 112)

iii. postvocalic / $\mathrm{r} /$ began to delete systematically in the seventeenth and eighteenth centuries. (Lass 1992: 66)

iv. From the late seventeenth century there are inverse spellings suggesting loss in unstressed syllables: e.g. operer 'opera', Bavarior 'Bavaria'. (Lass 2006: 92)

v. The last observation is particularly insightful since this might be a manifestation of hypercorrection, which is common in the final stages of language change and indicates insecurity as to when a (socially valued) feature should be used or not (J. Milroy 1992; cf. also Schreier 2005). There is thus strong evidence that non-rhoticity was pre-eminent by 1800 , in London and throughout the English Southeast, at least (but not in the English North and Southwest, Scotland, Ireland and Wales):

vi. The weakened $/ \mathrm{r} /$ after a vowel must have disappeared in the eighteenth c. Viëtor quotes Arnold 1718 as the earliest grammarian to speak of mute $r$ in mart, borough, parlour, scarce; König 1748 gives $r$ as mute in horse, parlour, partridge, thirsty. (Jespersen 1949: §13.24)

The loss of rhoticity in the English South is therefore a process that stretched about five centuries, starting in about 1300 and reaching completion in around 1800 . Whereas there are only sporadic manifestations early on, the innovation gathers pace in around 1600 and is adopted about two hundred years later. The emerging time frame mirrors what is one of the most persistent findings in social dialectology: the S-curve as a model of language change (Labov 1994). It is during the initiation phase that an innovation makes a first appearance, often lingering for considerable amounts of time as a minority variant; it is hardly ever noticed and commented on by the general public. Later on, in the expansion phase, it is used more commonly, by more members of the speech community and in more and more social contexts, so that it competes with existing (or 
chronologically older) forms. Upon successful adoption, it finally undergoes a termination phase, after which it is by and large socially accepted and quasi-normative (despite the fact that a small number of items are not affected). This model has been reconfirmed time and time again in studies of language change, for instance in the progress of pluralisation in English (the spread of the $-s$ suffix; McMahon 1994, cf. also Kroch 1989).

Consequently, when looking at phonological inventories of regional varieties of English around the world, then language contact alone will not do as an explanation. It might be a complicating factor (as witnessed by the fact that practically no pidgin or creole variety is rhotic), but the progress of $\mid \mathrm{r} />\varnothing$ in the British Isles and the timing of colonisation are of at least equal importance. To account for the criss-cross pattern and regional distribution of rhoticity on a global scale, one has to bear the following two considerations in mind: (1) The progress of the change from $/ \mathrm{r} /$ to $\varnothing$ in the British Isles; and (2) The timing of colonisation and arrival of English settlers in the respective colonies. Special emphasis has to be given to the seventeenth and eighteenth centuries, since this was the period of greatest fluctuation and variation with regard to the loss of rhoticity.

By comparing the dates of colonial expansion and the progress of the innovation in BrE, we can draw a dividing line in about 1750: colonies settled before the $1750 \mathrm{~s}$ are by and large rhotic or partially rhotic (North America, Ireland, Scotland, some parts of the Caribbean), those settled after the 1750s non-rhotic (Africa, Pacific, Southern Hemisphere in general). With regard to the speed of the process, an ongoing change had not progressed far enough to "make it" in colonies established before 1750 (since the change was still incipient in the English South, on the slow stage of the S-curve); later on, by contrast, it had progressed far enough to be picked up and adopted permanently in colonies established after 1750 (since $\mathrm{BrE}$ was in the expansion phase of the S-curve). As a result, there is a socio-historical explanation for a complex pattern of variation with regard to (non-)rhoticity in English around the world; a global look at phonological inventories obscures the historical and sociolinguistic motivation for its manifestation, and it is only the additional filtering-in of such information that can help explaining why these patterns manifest themselves the way they do (and not in any other way they could have theoretically done). This point is strengthened by the fact that regional forms of larger varieties partake in changes when they have prolonged contact with the 'mother country'. Non-rhoticity in White AmE may be in the progress of disappearing, but it is still found in South Carolina and in New England, precisely in those areas that kept in with England for much longer than the rest of the country (so long, in fact, that they adopted the innovation that 
had now become a majority variant in the speech of settlers from England). Partially rhotic varieties (e.g. in the Caribbean), on the other hand, may be regarded as a consequence of incomplete accommodation in a sociolinguistically diverse contact scenario, with additional effects of pidginisation and creolisation as well as second language learning. While the English input was highly variable and unstable, contact-induced change may have had a strong effect here (particularly phonotactic transfer). Finally, though rhoticity served as an illustration of the regional manifestation of change mechanisms, other examples would yield a similar picture. The major southern hemisphere varieties, for instance, are not only non-rhotic, they are also characterised by a general tendency to raise short front vowels and retracted articulations of low back vowels and diphthongs, all of which are not typically found in northern hemisphere varieties and can be explained by the timing of their settlement histories (Trudgill 2004). The case is further strengthened by Philippines English, finally, which is fully rhotic since it was established at a comparatively late stage and had a fully rhotic input (of AmE).

\section{Conclusion}

To conclude, the regional manifestation of phonological inventories of English varieties around the world is certainly a complex issue. Very often, individual structures cluster and are found in some regional varieties only; these may be confined to a particular region, though it is more common that they make a parallel appearance in diverse regions. The 'fuzzy' character of areal linguistics (not only of English, but generally) is explained by the fact that it is often not clear whether features in question are shared due to direct transmission in face-to-face contact, and thus diffused from one variety to the other, or whether they are inherited from a common parent language, an issue that looms large here as well.

Perhaps the principal question in this context is why varieties get to have their features and in what way they are similar to - or different from others (Hickey 2004). I would suggest that the complex criss-cross patterns that emerge from studies of English as a world language are in fact the result of several factors. First of all, we have to take into account the different local contact ecologies (Mufwene 2001) and their multi-faceted sociolinguistic characteristics: sociodemographics and social stratification certainly play a role in shaping the evolutionary path of new varieties, accompanied by all kinds of transfer effects (as evidenced by the case of CCR). Second, we have to look at the nature of the inputs and the pro- 
perties they (in theory at least) could leave as a legacy to the respective varieties. Here the timing of colonisation is of importance since British donor varieties partake in changes within British English at large, and this directly influences the output, i.e. the regional varieties around the world and their phonological inventories (rhoticity serves as an excellent example here). As Roger Lass said, the emerging patterns are "both gradual and complex"; however, by bringing together whatever social, linguistic and historical information there is available, we can shed some light on the issue and get a better understanding as to why varieties get (and got) to have the phonological features they have.

\section{References}

Bailey, Richard W.

1996 Nineteenth Century English. Ann Arbor: University of Michigan Press. Bayley, Robert

1994 'Consonant cluster reduction in Tejano English', Language Variation and Change 6: 303-327.

Campbell, Lyle

1998 Historical Linguistics: An Introduction. Cambridge MA: MIT Press.

Chambers, J, K.

2004 'Dynamic typology and vernacular universals', in: Bernd Kortmann (ed.) Dialectology Meets Typology: Dialect Grammar from a CrossLinguistic Perspective. Berlin: Mouton de Gruyter, pp. 127-146.

2009 Sociolinguistic Theory: Linguistic Variation and its Social Significance. Third edition. Chichester, UK and Malden, MA: Wiley-Blackwell.

Chambers, J. K. and Peter Trudgill

1998 Dialectology. Second edition. Cambridge: Cambridge University Press.

Childs, Becky, Jeffrey Reaser and Walt Wolfram

2003 'Defining ethnic varieties in the Bahamas: Phonological accommodation in black and white enclave communities', in: Michael Aceto and Jeffrey P. Williams (eds) Contact Englishes of the Eastern Caribbean. Amsterdam and Philadelphia: Benjamins, pp. 1-28.

Crystal, David

1991 A Dictionary of Linguistics and Phonetics. Third edition. Oxford and Cambridge MA: Basil Blackwell.

Fasold, Ralph

1972 Tense Marking in Black English: A Linguistic and Social Analysis. Arlington VA: Center for Applied Linguistics.

Filppula, Markku, Juhani Klemola and Heli Paulasto (eds)

2009 Vernacular Universals and Contacts: Evidence from Varieties of English and Beyond. London: Routledge. 
Guy, Gregory

1991 'Explanation in variable phonology', Language Variation and Change 3: $1-22$.

1994 'The phonology of variation', in: Katharine Beals, Jeannette Denton, Robert Knippen, Lynette Melnar, Hisami Suzuki and Erica Zeinfeld (eds) Papers from the 30th Regional Meeting of the Chicago Linguistics Society, Volume 2: The Parasession on Variation in Linguistic Theory. Chicago: Chicago Linguistics Society, pp. 133-149.

Heine, Bernd and Tania Kuteva

2001 'Convergence and divergence in the development of African languages', in: Alexandra Y. Aikhenvald and Robert M. W. Dixon (eds) Areal Diffusion and Genetic Inheritance: Problems in Comparative Linguistics. Oxford: Oxford University Press, pp. 393-411.

Hickey, Raymond

2003 'How do dialects get the features they have? On the process of new dialect formation', in: Raymond Hickey (ed.) Motives for Language Change. Cambridge: Cambridge University Press, pp. 213-239.

2004 'Introduction', in: Raymond Hickey (ed.) Legacies of Colonial English: A Study of Transported Dialects. Cambridge: Cambridge University Press, pp. 1-30.

Jespersen, Otto

1949 A Modern English Grammar on Historical Principles. Part I: Sounds Khan, Farhat and Spelling. London: George Allen \& Unwin Ltd.

1991 'Final consonant cluster simplification in a variety of Indian English', in: Jenny Cheshire (ed.) English Around the World: Sociolinguistic Perspectives. Cambridge: Cambridge University Press, pp. 288-298.

Kortmann, Bernd, Edgar W. Schneider, Clive Upton, Rajend Mesthrie and Kate Burridge (eds)

2004 A Handbook of Varieties of English. Vol. 1: Phonology. Berlin/ New York: Mouton de Gruyter.

Kroch, Anthony

1989 'Function and grammar in the history of English: Periphrastic do', in: Ralph Fasold and Deborah Schiffrin (eds) Language Variation and Change: Current Issues in Linguistic Theory. Philadelphia: John Benjamins, pp. 133-172.

Labov, William

1972 Sociolinguistic Patterns. Philadelphia: University of Philadelphia Press.

1994 Principles of Linguistic Change. Oxford: Blackwell.

1997 'Resyllabification', in: Frans Hinskens, Roeland van Hout and Leo Wetzels (eds) Variation, Change and Phonological Theory. Amsterdam and Philadelphia: John Benjamins, pp. 145-179. 
Lass, Roger

1992 'Phonology and morphology', in: Nicholas F. Blake (ed.) The Cambridge History of the English Language. Cambridge: Cambridge University Press, pp. 23-155.

2006 'Phonology and morphology', in: Richard Hogg and David Denison (eds) A History of the English Language. Cambridge: Cambridge University Press, pp. 43-108.

Lee, Ho-Joung

2000 'The pronunciation of English consonant clusters by Koreans', (Revised version of a paper presented at the Second International Conference of Phonetic Sciences, held in San Francisco CA). Online: http://www.ksps. or.kr/data/papers/40/79.pdf (accessed 12 July 2005).

Mair, Christian

2003 'Kreolismen und verbales Identitätsmanagement im geschriebenen jamaikanischen Englisch', in: Elizabeth Vogel, Antonia Napp and Wolfram Lutterer (eds) Zwischen Ausgrenzung und Hybridisierung. Würzburg: Ergon, pp. 79-96.

McArthur, Tom (ed.)

1992 The Oxford Companion to the English Language. Oxford: Oxford University Press.

McMahon, April M. S.

1994 Understanding Language Change. Cambridge: Cambridge University Press.

Milroy, James

1992 Linguistic Variation and Change: On the Historical Sociolinguistics of English. Oxford and Cambridge, MA: Blackwell.

Mufwene, Salikoko

2001 The Ecology of Language Evolution. Cambridge: Cambridge University Press.

Orton, Harold et al.

1962-71 Survey of English Dialects: Basic Materials. Introduction and 4 vols. Leeds: E. J. Arnold and Son.

Patrick, Peter L.

1991 'Creoles at the intersection of variable processes: $-t$, $-d$ deletion and past marking in the Jamaican mesolect', Language Variation and Change 3: 171-189.

1999 Urban Jamaican Creole: Variation in the Mesolect (Varieties of English around the World G17). Amsterdam and Philadelphia: John Benjamins.

Poplack, Shana and Sali Tagliamonte

2001 African American English in the Diaspora. Oxford: Blackwell.

Santa Ana, Otto

1996 'Sonority and syllable structure in Chicano English', Language Variation and Change 8: 63-91. 
Schreier, Daniel

2005 Consonant Change in English Worldwide: Synchrony Meets Diachrony. (Palgrave Studies in Language History and Language Change 3). Houndmills/Basingstoke and New York: Palgrave Macmillan.

2008 St Helenian English: Origins, Evolution and Variation. (Varieties of English Around the World G37). Amsterdam and Philadelphia: John Benjamins.

Strang, Barbara

1970 A History of English. London: Methuen.

Tagliamonte, Sali and Rosalind Temple

2005 'New perspectives on an ol' variable: (t, d) in British English.' Language Variation and Change 17: 281-302.

Thomason, Sarah G.

2001 Language Contact: An Introduction. Edinburgh: Edinburgh University Press.

Thomason, Sarah G. and Terrence Kaufman

1988 Language Contact, Creolization, and Genetic Linguistics. Los Angeles: University of California Press.

Torbert, Benjamin

2001 'Tracing Native American language history through consonant cluster reduction: The case of Lumbee English', American Speech 76.4: 361387.

Trudgill, Peter

2001 'On the irrelevance of prestige, stigma and identity in the development of New Zealand English phonology.' New Zealand English Journal 15: 42-46.

2004 New Dialect Formation: The Inevitability of Colonial Englishes. Edinburgh: Edinburgh University Press.

van der Auwera, Johann (ed.)

1998 Adverbial Constructions in the Languages of Europe. (Empirical Approaches to Language Typology - EUROTYP 20-3). Berlin: Mouton de Gruyter.

Wells, John C.

1982 Accents of English. 3 vols. Cambridge: Cambridge University Press.

Wolfram, Walt and Erik R. Thomas

2002 The Development of African American English. Malden, MA: Basil Blackwell. 
Bereitgestellt von | UZH Hauptbibliothek / Zentralbibliothek Zürich Angemeldet Heruntergeladen am | 27.11.17 13:55 